\title{
INTERNATIONAL HUMANITARIAN LAW
}

DOI: https://doi.org/10.24833/0869-0049-2020-4-81-94

\section{Alexandra Yu. Skuratova}

Moscow State Institute of International Relations (MGIMO-University) MFA Russia

76, Prospect Vernadskogo, Moscow, Russian Federation, 119454

interlawmgimo@bk.ru

ORCID: 0000-0001-8513-8719

\section{Elena E. Korolkova}

Prosecutor's office of the Orenburg region

51, Ul. Kobozeva, Orenburg, Russian Federation,460000

korolkovaintlaw@gmail.com

ORCID: 0000-0001-8932-5044

\section{PRIVATE MILITARY AND SECURITY COMPANIES IN INTERNATIONAL LAW}

INTRODUCTION. The article analyses the sources of international law, national legislation of the Russian Federation, as well as that of certain foreign States regulating the operation of private military and security companies (PMSCs) in armed conflict. The article highlights the outcomes of the work of the UN Special Rapporteurs and Working Groups to study the activity of PMSCs and the impact it had on the observance of human rights. The authors further analyze the status of PMSC personnel under international humanitarian law. The article also looks at the positions expressed by the delegations of Member States during the discussion of the 2010 Draft Convention on Private Military and Security Companies (PMSCs) and provides recommendations for developing an appropriate international regulatory framework. The authors also examined State practice of the implementation of the The Montreux Document on Pertinent International Legal Obligations and Good Practices for States Related to Operations of Private Military and Security Companies During Armed Conflict related to the operation of private military and security companies during armed conflict.

MATERIALS AND METHODS. The article contains an analysis of the main sources of international law, the documents drafted by the United Nations International Law Commission, special rapporteurs and working groups on the matter, and State practice. It also addresses Russian and foreign legal scholarship.

From a methodological perspective, this study relied on the general scientific (analysis, synthesis, systemic approach) and private legal methods of knowledge (formallegal, comparative legal studies).

RESEARCH RESULTS. Based on the study, it is argued that an international treaty should be adopted to regulate the activities of PMSCs, which would establish mechanisms to monitor and hold PMSCs and their employees legally accountable.

KEYWORDS: private military and security companies, armed conflict, international humanitarian law, Montreux Document, combatants, civilians, direct participation in hostilities.

FOR CITATION: Skuratova A. Yu., Korolkova E.E. Private Military and Security Companies in International Law. - Moscow Journal of International Law. 2020. No. 4. P. 81-94. DOI: 10.24833 / 0869-00492020-4-81-94 


\section{МЕЖДУНАРОДНОЕ ГУМАНИТАРНОЕ ПРАВО}

DOI: https://doi.org/10.24833/0869-0049-2020-4-81-94

Исследовательская статья Поступила в редакцию: 01.10.2020 Принята к публикации: 04.12.2020

\section{Александра Юрьевна Скуратова}

Московский государственный институт международных отношений (МГИМО-Университет) МИД России

119454, Российская Федерация, Москва, проспект Вернадского, д.76

interlawmgimo@bk.ru

ORCID: 0000-0001-8513-8719

\section{Елена Евгеньевна Королькова}

Прокуратура Оренбургской области

460000, Российская Федерация, Оренбург, ул. Кобозева, д.51

korolkovaintlaw@gmail.com

ORCID: 0000-0001-8932-5044

\section{МЕЖДУНАРОДНО-ПРАВОВОЕ РЕГУЛИРОВАНИЕ ДЕЯТЕЛЬНОСТИ ЧАСТНЫХ ВОЕННЫХ И ОХРАННЫХ КОМПАНИЙ}

ВВЕДЕНИЕ. В статье анализируются источники международного права, акты национального права России, некоторьх иностранных государств, регулируюшие деятельность частных военных и охранных компаний (ЧВОК) в вооруженных конбликтах. Показаны результаmы работы специальных докладчиков и рабочих групп ООН по исследованию деятельности ЧВОК, их влияние на соблюдение прав человека. Проанализирован статус сотрудников ЧВОК с точки зрения норм международного гуманитарного права. Рассмотрены позииии делегаций государств-членов при обсуждении проекта конвениии 2010 2. о регулировании деятельности ЧВОК, предложены рекомендации для разработки соответствующего механизма международно-правового регулирования. Изучена практика применения государствами Документа Монтрё о соответствуюших международно-правовых обязательствах и передовых практических меmодах государств, касающихся функиионирования частных военных и охранных компаний в период вооруженного конфликта (Документ Монтрё) и Международного кодекса поставщиков охранных услуг.
МАТЕРИАЛЫ И МЕТОДЫ. В статье проведен анализ основных источников международного права, материаль работь Комиссии международного права ООН, специальных докладчиков u рабочих групп по этому вопросу, практика государств. Изучены доктринальные труды зарубежных и российских специалистов в области международного права. Методологическую основу исследования составили общенаучные (анализ, синтез, системный подход) и частноправовые методы познания (бормально-юридический, сравнительно-правовой).

РЕЗУЛЬТАТЫ ИССЛЕДОВАНИЯ. На основе проведенного исследования аргументируется необходимость принятия международного договора, регулирующего деятельность ЧВОК, что позволит создать механизмь для контроля $и$ привлечения к юридчческой ответственности ЧВОК и их сотрудников.

КЛЮЧЕВЫЕ СЛОВА: частные военные $u$ охранные компании, вооруженный конфликт, международное гуманитарное право, Документ Монтрё, комбатанты, гражданские тица, непосредственное участие в военных действиях. 
ДЛЯ ЦИТИРОВАНИЯ: Скуратова А.Ю., Королькова Е.Е. Международно-правовое регулирование деятельности частных военных и охранных компаний. - Московский журнал международного права. 2020. № 4. C. 81-94. DOI: 10.24833 / 0869-0049-2020-4-81-94

\section{Private Military and Security Companies - general provisions}

$\mathrm{P}$ rivate military and security companies provide armed security services, police, and military training, intelligence gathering and analysis, participate in peacekeeping missions, and complete other tasks [Gasser, Malzacher 2020:57-87]. The army and the police have traditionally performed most of these functions [Nebolsina 2019: 76-106]. Several factors are of concern in this context. Firstly, PMSC personnel tend to work in an area of armed conflict, exposing their lives to immediate danger, and, unlike military personnel, they are not afforded any legal guarantees [Lehnardt 2017: 761-780]. Most PMSC personnel involved in armed conflicts are nationals of third States not involved in armed conflict. The contracts they enter into often do not contain any provisions on the actual nature of work involving participation in hostilities, further constraining their access to obtain medical care and compensation in the event of injury or death. Second, not uncommon are the violations of international law committed by PMSC personnel, which prompted the UN Human Rights Commission to review the work of such companies and develop an appropriate legal framework.

\section{UN's work on the activities of Private Military and Security Companies}

\subsection{Outcomes of the work of the UN Special} Rapporteur on use of mercenaries as a means of impeding the exercise of the right of peoples to self-determination (1987-2005)

In 1987, the UN Commission on Human Rights appointed a Special Rapporteur on the use of mercenaries as a means of violating human rights and impeding the exercise of the right of peoples to self-determination, with a mandate to study, among others, the methods of recruiting mercenaries to take part in armed conflict. In 2005, the mandate expired. The UN Commission on Human Rights formed a Working Group of the same name.

The Special Rapporteur made the first mention of private companies providing military services in armed conflict in 1994. It was noted that former soldiers were recruited by the South African "Executive Outcomes" Company to participate in hostilities in Angola, supporting the UNITA rebels. This was in contravention of Angola's legislation at the time. Private companies were often involved in armed conflicts, both by the Governments and by non-state armed groups. For example, "Sandline International" contracted by the Government of Papua New Guinea, gathered intelligence, conducted military offensives in Bougainville, supplied arms, ammunition, and military equipment to the scene of hostilities. At the same time, the Defense Forces were placed under the command of the Company's personnel.

Upon analyzing the state practice of African states, the Special Rapporteur concluded that Governments allow the recruitment of mercenaries, enlisted via private military companies. He also noted that the notion of mercenaries was developing, transforming, and could often hide behind the façade of private military companies providing military assistance and expertise. The key ideas of the Special Rapporteur were:

- Upholding peace is an inherent obligation that a State cannot delegate; ${ }^{1}$

- As they progress and develop, private military companies may create a real threat to the governments; ${ }^{2}$

- Outsourcing state functions to private companies will limit state sovereignty. ${ }^{3}$

As a result of the study, the Special Rapporteur suggested that such companies be prohibited, as they encourage mercenary activities. However, this po-

\footnotetext{
1 Report of the Special Rapporteur on the use of mercenaries. January 13, 1999, E/CN.4/1999/11. URL: https://ap.ohchr.org/ documents/dpage_e.aspx?m=105 (accessed: 09.09.2020).

2 Report of the Special Rapporteur on the question of the use of mercenaries. February 20, 1997. E/CN.4/1997/24. URL: https://ap.ohchr.org/documents/dpage_e.aspx?m=105 (accessed: 09.09.2020).

3 Note by The Secretary-General on the Use of Mercenaries as a Means of Violating Human Rights and Impeding the Exercise of the Right of Peoples to Self-Determination. October 16, 1997, A/52/495. URL: https://ap.ohchr.org/documents/dpage_e. aspx?m=105 (accesed: 09.09.2020).
} 
sition later shifted to a proposal to develop a legal framework, should states deem legal the use of private military and security companies in armed conflict.

\subsection{Work of the UN Working Group on the use of mercenaries as a means of violating human rights and impeding the exercise of the right of peoples to self-determination (2005-present).}

The Working Group comprises five independent experts from different regions of the world, who serve on a rotating basis.

In 2008, a draft convention regulating PMSCs was proposed in Moscow by representatives of the Russian Federation as part of a regional consultation. It contained general provisions on the applicable terms and basic regulatory principles, principles of international law applicable to the activities of PMSCs, and provisions on the international legal responsibility of States for the acts of PMSCs.

In 2010, at the 65th session of the United Nations General Assembly, the Chair of the Working Group presented a draft convention regulating the activities of PMSCs, which was not adopted by the UN Member States, as some delegations criticized the text, as detailed below.

\subsection{The work of the Open-Ended Intergovernmental Working Group to consider the possibility of elaborating an international regulatory framework on the regulation, monitoring and oversight of the activities of pri- vate military and security companies} (2010 to 2017).

The UN Human Rights Council established an Intergovernmental Working Group to consider developing an international legal framework to regulate the monitoring and control of PMSCs based on the draft text proposed by the Working Group. ${ }^{4}$ Thirtytwo states (including Russia) voted in favor of the establishment of the Working Group, 12 voted against (United Kingdom, United States, etc.), and three abstained (Switzerland, etc.).

One of the key issues of discussion was identifying the reasons that had prevented the adoption of the Draft Convention proposed by the Work- ing Group in 2010. These reasons included the following:

- the provisions of the Draft Convention on the responsibility of states for the conduct of private persons are not in conformity with the rules of international law, in particular, the Draft articles on Responsibility of States for Internationally Wrongful Acts drafted by the UN International Law Commission;

- the Draft Convention envisions obligations for non-State actors (private military and security companies) who cannot proprio motu be parties to the Convention;

- the Draft Convention distinguishes between "inherently governmental functions," which PMSCs are prohibited from performing, and other functions that States may delegate. A common understanding of what "inherently governmental functions" are within the framework of the Convention, in the view of the experts, is problematic, given the different regulatory approaches of States on this issue;

- the Draft Convention provides for the establishment of a new body with powers to investigate complaints by victims, but does not contain any provisions outlining its funding and operation.

In the end, the delegates were divided on possible ways to design a regulatory framework. These include:

- basing the international legal framework on the Montreux Document on Pertinent International Legal Obligations and Good Practices for States Related to Operations of Private Military and Security Companies During Armed Conflict, 2008, and the International Code of Conduct for Private Security Service Providers, 2010. (This is the position of Great Britain);

- the need for an international treaty has not yet matured - we should better examine state practice should first be reviewed and, on its basis, draft a set of guidelines, distinguishing private security companies from private military companies (The US proposes to adopt a "plan of action" based on expert reports containing recommendations to States to regulate PMSCs). ${ }^{5}$

- an international treaty on the matter is required, as national legislation is rather fragmented, as PMSC employees violate human rights and are rarely held accountable.

\footnotetext{
4 Resolution adopted by the Human Rights Council. October 7, 2010, 15/26. URL: https://documents-dds-ny.un.org/doc/ UNDOC/GEN/G10/167/44/PDF/G1016744.pdf?OpenElement (accessed: 09.09.2020).

5 Fifth Session of the Open-Ended Intergovernmental Working Group on Private Military and Security Companies. U.S. Government Delegation Closing Statement. December 12-16, 2016. URL: https://www.ohchr.org/Documents/HRBodies/HRCouncil/WGMilitary/Session5/US_closing_statement.pdf (accessed: 09.09.2020).
} 
The fact that the discussions were going in different directions, as well as the existence of contradictory positions, led to the ultimate "freeze" of the debate on the adoption of an international treaty.

\subsection{The work of the new Open-ended} intergovernmental working group to elaborate the content of an international regulatory framework, without prejudging the nature thereof, relating to the activities of private military and security companies from 2017 to present.

In 2017, the UN Human Rights Council established a new Intergovernmental Working Group for three years to develop international legal mechanisms to regulate the activities of PMSCs.

The first and so far only session was held in 2019 . State delegations expressed different positions on possible regulatory mechanisms. Brazil, India, and Venezuela believed that the Montreux Document only reflects a fragment of existing international law that may cover the activities of PMSCs, yet this is not enough, as significant legal lacunae remain. Some delegations actively supported existing soft-law instruments. In particular, the European Union, Great Britain, and Switzerland posit that the Montreux Document and the International Code of Conduct ensure the protection of human rights and are sufficient to govern the PMSCs.

Cuba, Ecuador, and South Africa unequivocally advocated for the adoption of an international treaty. The delegation of Egypt noted the need to consider the differences in the national legislation of States concerning the establishment and operation of private military companies during the drafting process. Pakistan, while speaking in favour of the initiative to conclude an international treaty, proposed to harmonize the positions of States on mutual legal assistance, international state responsibility, and the accountability of PMSCs personnel in the military chain of command. Most of those in favour of adopting the treaty were those states where the PMSCs were active. Thus, the representatives of Iran and Iraq considered it necessary to draw lessons from past large scale violations of human rights and international humanitarian law in Iraq, Afghanistan and other States where PMSC personnel killed innocent civilians in cold blood, subjected them to torture and ill-treatment.

The delegation of the Russian Federation announced their intention to be an active member of the Working Group, drawing attention to the need to discuss a number of contentious issues (the legitimacy of
PMSCs, status of their personnel under international humanitarian law, functions that the State may delegate to PMSCs, responsibility for unlawful acts committed by employees of companies).

The session resulted in a synthesis of critical points agreed on by the participants. During the further stages of developing a legal framework, it is advisable to:

- take into account the distinction between mercenaries and PMSC employees;

- draw on the studies of Special Rapporteurs and Working Groups;

- take into account the national legislation of States applicable to PMSCs;

- determine the status of PMSC staff under international humanitarian law;

- develop a list of functions that States cannot delegate;

- to consider regulating the activity of PMSCs in "complex situations" involving participation in cyber operations, control of unmanned aerial vehicles and autonomous weapons systems [Skuratova, Korolkova 2019: 22-30];

- take stock of previous negative lessons learned with the use of PMSCs to destabilize constitutional regimes to prevent such practices;

- consider the development of differentiated regulatory mechanisms applicable in armed conflict and peacetime;

- $\quad$ not to differentiate between private military and private security companies by type of service, as such companies offer a wide range of services;

- to develop a mechanism for mutual legal assistance in criminal matters.

During the discussion, a rather contentious view was expressed that PMSCs could not be considered Parties to armed conflict because they were merely service providers. Accordingly, they are not subject to international humanitarian law. This position did not gain strong support [Sassòli, 2019:542-553].

\section{Status of personnel of private military and security companies under international humanitarian law}

\subsection{Mercenaries}

Additional Protocol I of 1977 to the Geneva Conventions of 1949 (AP I) and the International Convention against the Recruitment, Use, Financing and Training of Mercenaries of $1989^{6}$ set out cumulative

6 International Convention Against the Recruitment, Use, Financing and Training of Mercenaries, adopted by UNGA Res. 44/34 on 4 December 1989. 
criteria that can qualify a person as a mercenary. The absence of any criterion will automatically mean that a person cannot be a mercenary. For example, the criterion of private gain or material compensation is not always limited to material remuneration, because many PMSC employees are involved in an armed conflict, wishing to apply professional skills, and "get an adrenaline dose." The lack of citizenship or permanent residence in the territory of the State where the armed conflict is taking place does not prevent the employment of PMSC personnel. Companies employ locals to perform specific services [Gómez del Prado 2017:59-62]. Members of PMSCs are not included in the State's armed forces and therefore qualify as mercenaries under this criterion.

Consider the application of this article to specific PMSC staff members from Peru employed by the United States in the armed conflicts in Iraq and Afghanistan:

- contracts concluded with Peruvians provided for the conduct of training for subsequent participation in hostilities and the payment for such participation (partly subject to the requirements of paras. a and c of Art. 47 API, and para. A of Art. 1(1) of the 1989 International Convention);

- Peruvian recruits were neither nationals, nor residents of the parties to armed conflicts (requirement of p. "d" art. 47 AP I, p. "c" c. art. 1, para. 1 of the 1989 International Convention);

- were not military personnel of the United States or any other party to the conflict (requirements of paragraphs "e" and "f" art. 47 AP I, para. "d" c. 1, art. 1 of the 1989 International Convention);

- not officially sent by the State (Peru) for the performance of tasks in situations of armed conflicts (para. "f" AP I, para. "e" para. 1, art. 1 of the 1989 International Convention).

In this case, there is no basis for the qualification of PMSC personnel as mercenaries under Art. 47 AP I and art. 1 International Convention of 1989, because not all the criteria set out in the documents have been met.

\subsection{Status of PMSC personnel in armed conflict of an international character.}

International humanitarian law grants certain participants in armed conflict the right to directly participate in hostilities.

1. Members of the armed forces shall have the right to take part directly in hostilities, according to Art. 1, para. 4A of the 1949 III Geneva Convention, Members of armed forces are persons belonging to the armed forces of a party to the conflict. ${ }^{8}$ If the State has not provided a notification that paramilitary and police groups are incorporated into the armed forces, they will not qualify as combatants. This requirement may apply to PMSC personnel involved in armed conflict.

2. International law recognizes the persons who, "on the approach of the enemy spontaneously take up arms to resist the invading forces, without having had time to form themselves into regular armed units, provided they carry arms openly and respect the laws and customs of war" as combatants. ${ }^{9}$ However, this case does not apply to PMSC staff members, as their participation in armed conflict is preconditioned on the existence of a contract.

3. Members of the resistance movements also enjoy combatant status. The International Committee of the Red Cross (ICRC) interprets belonging to a Party to conflict as the existence of a de-facto relationship between the participants in the resistance movement and a Party to the conflict. There must be a substantial nexus between the two. The requirements are set out in Art. 1 of the 1907 Convention on the Laws and Customs of War on Land:

- to be commanded by a person responsible for his subordinates;

- $\quad$ to have a fixed distinctive emblem recognizable at a distance;

- $\quad$ to carry arms openly; and

- to conduct their operations in accordance with the laws and customs of war. ${ }^{10}$

Some PMSC personnel may be considered combatants if they comply with the above criteria.

\footnotetext{
7 Gómez del Prado J.L. Impact on Human Rights of a New Non-State Actor: Private Military and Security Companies. URL: http://www.privatesecurityregulation.net/files/Impact\%20in\%20Human\%20Rights\%20of\%20Private\%20Military\%20 and\%20Security\%20Companies\%27\%20Activities.pdf (accessed: 09.09.2020).

8 Third Geneva Convention III, relative to the treatment of prisoners of war 1949.

9 Art. 10 Brussels Declaration 1874 r., Art. 2 Hague Convention 1907 r., Art. 4(A)(6) Third Geneva Convention, relative to the treatment of prisoners of war 1949.

10 Hague Convention, respecting the Laws and Customs of War on Land 1907.
} 
Art. 4A(4) of the Third Geneva Convention 1949 established that the persons who have received authorization from a party to the conflict "to accompany the armed forces without actually being members thereof" are entitled to the status of a prisoner of war". "This is confirmed by a special permit issued by the government. In the United States, according to the Instruction of the Department of Defense "On Contractor Personnel Authorized to Accompany the US Armed Forces" ${ }^{\text {"12 }}$ PMSCs personnel are civilians, accompanying the armed forces, who, however, often take direct part in hostilities, abusing their rights.

Questionable is the practice of some States concerning the recruitment of PMSC personnel to guard military installations [Crawford, Pert 2015: 226231]. If PMSC personnel act as civilians, the defending Party is responsible for protecting military objectives and facilitating military operations. Defending a PMSC military facility would be considered an act of violence against the enemy.

In summary, the status of PMSC personnel in situations of international armed conflict must be determined on a case-by-case basis [Cockayne 2014: 737]. PMSCs personnel cannot be unequivocally qualified as mercenaries because their activities only partially meet the criteria set out in Art. 47 of AP I to the Geneva Conventions of 1949 and international treaties dealing with mercenarism. In some cases, PMSC personnel may enjoy the rights and obligations of combatants, including the status of prisoners of war. According to prof. Kotlyarov I.I., PMSCs may be incorporated into the armed forces, despite the private nature of their activities, under a license issued under national legislation that makes this possible [Kotlyarov 2013:176]. Where PMSCs act as consultants and provide security advice or logistical support, they are civilians [De Nevers 2017:281-302].

\subsection{Status of PMSC personnel in a non-interna- tional armed conflict.}

In most cases, PMSC personnel are involved in non-international armed conflicts where there are hostilities between organized (non-governmental) armed groups and the armed forces of a State. The participation of PMSCs on the side of government forces may be subject to a contract signed with the Government of the State. Foreign PMSCs may participate in such armed conflicts only with the consent of the receiving State.

Nevertheless, PMSCs do get employed by nonstate armed groups in situations of armed conflict of a non-international character [Daza 2017:31-57]. The participation of foreign PMSCs on the side of organized armed groups sent by a foreign State in a non-international armed conflict may be regarded as an intervention in the domestic affairs of the State. An example of this is the United States and British PMSCs, who were involved in armed conflicts in Libya in 2001 and Syria in 2011.

The purpose of international humanitarian law is, first and foremost, to protect civilians through compliance by Parties to an armed conflict with the duty to distinguish between combatants and civilians.

1. The status of government armed forces is defined in AP I, which also applies to non-international armed conflict. A person's membership in the armed forces is determined by national legislation.

2. In order to determine whether an individual belongs to an organized armed group, one must determine whether he or she has a permanent function within the group. Members of an organized armed group cease to be considered civilians for as long as they remain members of the group as long as they have an active combat function. At the same time, if a person only sporadically provides acts for an organized armed group, he or she cannot be considered to be a member of one, since it is necessary to have a long-term connection with the group [Rusinova 2012:61-69].

According to the commentary to AP II, direct participation in hostilities is "military actions which, by nature or purpose, are likely to cause actual harm to the personnel and damage equipment of the enemy's armed forces." ${ }^{13}$ The term "direct participation in hostilities" is not disclosed in any international legal document. However, a precise understanding of what constitutes direct participation in hostilities is essential in determining the status of a party to a non-international armed conflict.

\footnotetext{
11 Third Geneva Convention III, relative to the treatment of prisoners of war 1949.

12 Instruction of the Department of Defense on Contractor Personnel Authorized to Accompany the US Armed Forces, № 3020.41 from 03.10.2005.

${ }_{13}$ Commentary to Additional Protocol II, of 8 June 1977, to the Geneva Conventions of 12 August 1949, relative to the protection of victims of non-international armed conflicts: Translated from English K. Piytu et. al. - 2 Edition., Moscow, International Committee of Red Cross, 2000, p. 303.
} 
In light of this gap, the ICRC's attempt to interpret the term is welcome. ${ }^{14}$ The ICRC experts propose that several constituent elements should be taken into account to define an action as direct participation in hostilities:

- the action must, as a probable result, adversely affect the military operations or military capabilities of a party to the conflict or cause death, injury, or destruction to the persons or objects protected from an imminent attack (threshold of harm);

- there must be a direct causal link between the acts and the harm that may result from the act or the coordinated military operation (direct causation);

- the action must be specifically designed to achieve the threshold of harm and must be performed in support of one party to the conflict and to the detriment of the other (belligerent nexus).

The commentary to AP II provides that direct participation in hostilities is an act of war, which, by its nature and purpose, may have the probable result of actual damage to the personnel and equipment of the enemy forces. The International Tribunal for the Former Yugoslavia in the criminal case "Prosecutor v. Strugar" reached similar conclusions ${ }^{15}$.

Based on this, the activities of PMSCs in the training of military personnel and the development of general plans of military operations (for example, such American companies: "Cubic Application International", "Kellog, Brown and Root", "MPRI" in Georgia during the Georgian-Ossetian conflict in 2008) and intelligence gathering, which are not directed at a specific military operation, do not constitute direct participation in hostilities.

On the other hand, the supply of arms for a specific military operation does constitute direct participation in hostilities (e.g., employees of "Sandline International" in 1998 supplied arms to participants of armed conflicts in the territory of the former Yugoslavia, in Iraq, Bahrain, Qatar, and Sierra Leone) [Mathieu, Rearden 2007: 744-755].

In addressing the status of PMSCs personnel in non-international armed conflict, one must estab- lish the functions that they perform in the course of their participation in armed conflict since not all functions are related to military action. For example, most of these companies provide logistical services. Thus, if such PMSC personnel support an organized armed group in this manner, they will not receive POW status in case of enemy capture.

For a long time, States had contracted private companies whose employees were to directly take part in hostilities. Thus, when the governments of individual African states employed PMSCs to respond to the insurgency, they helped to quell resistance and keep the political regimes in force. These Governments excused this practice due to the lack of adequately trained armed forces and comparatively lower costs, as opposed to maintaining the army.

Ultimately, the right of PMSCs personnel to directly participate in the hostilities will depend on the existence of guarantees as well the State's ability to ensure that these functions are carried out without compromising security. However, based on numerous studies by domestic and foreign scholars on the involvement of PMSCs in armed conflicts, the ban on their participation in hostilities seems justified.

In conclusion, international humanitarian law affords different protection to civilians and combatants; at the same time, it is becoming increasingly difficult to draw a line between the two categories in modern armed conflicts. ${ }^{16}$ This is primarily due to the nature of armed conflicts, the emergence of various non-State actors taking part in hostilities, and the use of new combat operations technologies.

The rules of IHL have changed since the First World War, with the adoption of the 1929 Geneva Conventions, their revision after the Second World War in 1949, and then in 1977, during the struggle against colonialism [Sassòli 2019: 542-553]. However, the emergence of new, previously unknown methods of warfare requires the international community to review the existing IHL. Based on the above, we can assume that PMSC personnel would not enjoy the status of either combatants or civilians, but would be treated as sui generis actors.

\footnotetext{
14 Interpretive guidance on the notion of direct participation in hostilities under international humanitarian law: International Committee of the Red Cross. Geneva, 2009.

15 Prosecutor v. Pavle Strugar, IT-01-42-AR72 (Decision on Interlocutory Appeal). November 22, 2002.

${ }^{16}$ Durham H. Strengthening Compliance with IHL : Disappointment and Hope ICRC, Humanitarian Law \& Policy Blog, 2018. URL: https://blogs.icrc.org/law-and-policy/2018/12/14/strengthening-compliance-with-ihl-disappointment-and-hope/ (accessed: 09.09.2020).
} 


\section{National legislation concerning PMSCs}

On September 2007, members of the PMSC called "Blackwater" carried out an armed attack on civilians, including women and children, at the Nisour Square in Baghdad. The FBI investigated the killing and injuring of civilians. The Iraqi authorities failed to prosecute PMSC personnel because they were entitled to immunity from criminal prosecution, as granted under the Order of the Iraqi Coalition Provisional Authority No. 17 (2004). The PMSC's presence in Iraq was against the law, as the military and security services license issued by the Ministry of the Interior expired on 1 February 2006.

In the United States, criminal prosecution of PMSCs personnel is governed by the Military Extraterritorial Jurisdiction Act (MEJA) and the Uniform Code of Military Justice (UCMJ).

Under MEJA, federal courts exercise jurisdiction over crimes committed outside the United States by persons employed or accompanying the armed forces, or by US military personnel. MEJA covers civilians contracted by the United States Department of Defense or other federal agencies that employed them in support of a DOD mission. ${ }^{17}$ Four employees of "Blackwater" were prosecuted and convicted of various crimes committed in violation of MEJA. In the course of the trial, the defense pleaded that MEJA did not apply to Blackwater employees. In support of the claim, the defence argued that the US Federal Court had no jurisdiction, as MEJA applied only to crimes committed by PMSC employees hired under contract with the United States Department of Defense or pursuant to the mission of the Department of Defense, and not with any other agency (in the case in question, the contract was concluded by the Department of State).

As for UCMJ, it had previously only been applied to members of armed forces, while the prosecution of civilians was beyond its scope. With the amendments, UCMJ's jurisdiction extended to PMSC employees. ${ }^{18}$ However, the prevailing fraction of the foreign legal scholarship posits that the application of the UCMJ to PMSC employees violates their con- stitutional rights under the Fifth and Sixth Amendments to the United States Constitution, as they are considered civilians under United States law.

The prosecution of PMSCs personnel for the crimes committed is further complicated by bilateral agreements granting them immunity from prosecution by the competent authorities. The existence of such agreements should not absolve sending States of responsibility for holding the perpetrators accountable and ensuring justice.

The US Alien Tort Statute ("ATS") grants foreign nationals who have been injured by PMSCs' or their employees' actions the right to file a civil suit for damages. ${ }^{19}$ In 2004, citizens of Iraq who were tortured by employees of "Titan" and "CACI" filed a civil action for the violation of the norms of international law. ${ }^{20}$ In 2004, a civil action was filed. The United States District Court denied the claims, arguing that the ATS did not apply to private actors [Bakker, Sossai 2012: 664].

In the case of "Abtan v. Blackwater", the trial followed from a class action brought by the Iraqi citizens injured by the shelling perpetrated by the employees of the PMSC "Blackwater" in Baghdad. The representatives of "Blackwater" during the trial cited their status as non-state actors and argued that they could not be responsible for violation of norms of international law. In 2009, the court decided in favour of "Blackwater," rejecting the claims of the prosecution. ${ }^{21}$

Some states have enacted laws to regulate such companies. Private companies are prohibited in most States, so de jure private military companies do not exist (e.g., Russia, China, Germany, Egypt, etc.). South Africa has enacted a special Private Security Act of 2001 and a Code of Conduct for Security Service Providers of 2003. Employees of such companies may only provide security services. ${ }^{22}$ A similar approach is reflected in Swiss legislation governing private security activities abroad. The law prohibits private company employees from taking a direct part in hostilities.

The legislation of some States does not explicitly prohibit the activities of PMSCs involved in armed

\footnotetext{
1718 U.S. Code Chapter 212 - Military Extraterritorial Jurisdiction Act, § 3261-3267.

1810 U.S. Code Chapter 47 - Uniform Code Of Military Justice, $§ 802$, (a) (10).

1928 U.S. Code $\S 1350$ - Alien's action for tort.

20 Saleh v. Titan Corp., 436 F. Supp. 2 d 55 (D.D.C. 2006).

21 Estate of Abtan v. Blackwater Lodge Training Center, 611 F. Supp. 2 d 1 (D.D.C. 2009).

22 The Regulatory Framework of PMSCs in South Africa. Working Group On The Use Of Mercenaries As A Means Of Violating Human Rights And Impeding The Exercise Of The Rights Of Peoples To Seld-Determination. URL: https://www.ohchr.org/EN/ Issues/Mercenaries/WGMercenaries/Pages/WGMercenariesIndex.aspx (accessed: 09.09.2020).
} 
conflict (Sudan). Some constitutions prohibit public functions, such as the administration of justice and the provision of national security to private companies (France, Algeria, Tunisia).

The constitutions of Russia and Yemen prohibit the establishment of non-State armed groups. In Russia, the state security is a function of the national armed forces. Specific task can be delegated to various groups, as well as special services. Article 208 of the Russian Criminal Code prescribed criminal responsibility for creating, directing, financing and participating in an illegal armed group, which means that any other armed formations must specifically follow out of federal law, allowing their establishment. In the absence of specific regulation, the activities of PMSC employees may be characterized as mercenarism under Art. 359 of the Russian Criminal Code.

In summary, the existing national legislation is a diverse mosaic, and does not contribute to developing general practice in the use of PMSCs. There are difficulties in prosecuting and collecting evidence in criminal cases. Analysis of the legislation of individual States revealed significant differences in the level of regulation of PMSCs. This applies to the different approaches to the formulation of the applicable terminology, the range of services that such companies are entitled to provide.

\section{2010 Draft Convention and its criticism}

In 2010, the Chair of the Working Group at the 65th session of the UN General Assembly presented a draft convention to regulate the activities of PMSCs. The need to adopt a legally binding instrument was driven by the desire to establish minimal international standards applicable to PMSCs.

Article 2 of the Convention defines various terms used throughout the text. In particular, the following definition is proposed for PMSCs: "a corporate entity which provides on a compensatory basis military and/or security services, including investigation services, by physical persons and/or legal entities." The text goes on to list the permitted services.

A number of foreign scholars have criticized these provisions of the draft Convention, pointing out that the definition of PMSCs is open to broad interpretation and can be applied to any contractor [Seiberth 2014: 296], while the list leaves open the question as to what functions are permissible for PMSCs.

Part II of the Draft Convention sets out general regulatory principles. Part III deals with the national regulation and monitoring, the obligation to license the services of PMSCs, the establishment of a national registry, the obligation to train and vet the personnel of PMSCs, as well as compliance with labour laws, and the regulations governing the use of force and firearms by PMSC personnel.

Obligations of States parties in the application of civil and/or administrative sanctions against offenders and the provision of remedies to victims are set out in Part IV. The draft convention proposes that only performance of State functions by employees of PMSCs, illegal use of force and firearms, illegal use of certain weapons, and illegal trafficking in weapons by PMSCs and their personnel may be qualified as crimes under domestic legislation.

In addition, any activity carried out by PMSCs in the absence of a specific authorization shall be illegal. States parties must ensure that perpetrators are brought to justice and provide effective remedies to victims. This part of the draft convention contains provisions on the civil liability of legal and natural persons, the establishment of State jurisdiction, and obligations relating to the prosecution and extradition of nationals.

Part V deals with establishing a committee on the Regulation, Oversight, and Monitoring of PMSCs. The Committee is envisioned to receive reports from States parties on the legislative, judicial, administrative and other measures they have adopted, in accordance with the procedures established in international human rights instruments, to implement the provisions of the Convention. At the same time, the draft convention provided for an inquiry procedure and an individual complaints procedure.

The draft proposed that the Secretary-General create an international registry of PMSCs active in the global market, which would be based on the information submitted by member states.

UN Member states never adopted the Draft Convention, with some delegations criticizing the text. In particular, based on the text, it is not possible to establish the status of PMSCs personnel in accordance with the rules of IHL. One delegation criticized the conditions for the application of the Convention (situation of armed conflict), noting the narrow focus of the draft convention, which did not take into account other complex situations where private armed forces were involved (for example, the destabilization of the constitutional regime, emergency operations, etc.). In our view, the Convention should not apply to all situations involving the activities of PMSCs, as this can be regulated at the level of national legislation, which, in any event, is already the case across a number of States. 
Furthermore, the draft convention refers the Victims' Compensation Fund, but does not specify its status, funding or working mechanism, which makes the rule virtually inapplicable and requires further detail.

Note should be taken on the approach taken by the drafters of the Convention in formulating the obligation of States to take all necessary legislative measures, licensing regimes, contracting and training requirements, oversight and monitoring requirements. The existence of such a duty could spark conflicts between different national legal regimes with regard to compliance with licensing requirements. Furthermore, the establishment of such regulatory mechanisms would entail significant financial costs for States, which would act as a deterrent to ratification.

With regard to the problem of the use of the term "inherently governmental functions", there is no agreed definition in international law of what these functions are.

An examination of the use of PMSCs revealed abuses due to the lack of control over their activities during armed conflict. In this connection, it is logical that the experts of the United Nations Working Group should take the initiative to give military commanders the power to monitor the PMSCs staff, since it is the commanders who bear the obligation to comply with the rules of international humanitarian law.

\section{Alternative legal frameworks}

To regulate the activities of PMSCs in armed conflicts, the Government of Switzerland and ICRC held international consultations, which resulted in the adoption of the Montreux Document in 2008 and the International Code of Conduct for Private Security Service Providers in 2010 (further - "International Code of Conduct"). As of September 2020, 7 States acceded to the International Code of Conduct: Australia, Canada, Norway, Sweden, Switzerland, United Kingdom and the United States of America, 97 PMSCs, and 38 non-governmental organizations. ${ }^{23}$

At the time of signature, only 17 States acceded to the Montreux Document, but the number now stands at 56. In addition to States, the EU, OSCE, and NATO have joined the Montreux Document. The
Russian Federation has not signed this instrument due to the Russian experts' opinion that the Montreux Document was developed to serve the interests of a certain group of States, who rely on the services of PMSCs. Therefore, according to them, the document does not take into account the interests of other countries. In addition, Russian legislation does not provide for the activities of such companies.

The document consists of two parts. The first one draws a difference between the legal status of States according to the obligations under international law: such contracting States, territorial States and third States. The second part of the document references good practices developed for implementing the obligations set out in the first part: the procedure for the selection of PMSCs and the conclusion of contracts, the procedure for the authorization of military and security services, and the monitoring of compliance. Good practices summarise the current practice of those states who have resorted to PMSCs. The preface to the Montreux Document states that it is legally binding and "should not be construed as endorsing the use of PMSCs in any particular circumstance ${ }^{\text {"24. }}$.

The Montreux Document identified general recommendations addressed to States, including:

- not to contract PMSCs to carry out activities that international humanitarian law explicitly assigns to a State agent or authority (para. 2, section "A" c. 1) (performing inherently governmental functions);

- take appropriate measures to prevent, any violations of international humanitarian law by personnel of PMSCs; (para. "c" para. 3, section "A", para. 1);

- $\quad$ to investigate and, ensure effective judicial proceedings (para. 6, section "A", para. 1);

- to ensure respect for international humanitarian law by disseminating information about it (subparas. "a", "b", para 3 section "A", para. 1).

The contracting State (a term used by the Montreux Document) bears the majority of the obligations, such as the duties not to contract PMSCs to carry out inherently governmental activities; contracting with PMSCs to perform exclusively State functions; to select and contract PMSCs, whose personnel have had proper training; to take measures to comply with international humanitarian law; to prevent and investigate violations committed by PMSCs

\footnotetext{
${ }^{23}$ International Code of Conduct Association. URL: https://www.icoca.ch (accessed: 09.09.2020).

24 The Montreux Document on Pertinent International Legal Obligations and Good Practices for States Related to Operations of Private Military and Security Companies During Armed Conflict. International committee of the Red Cross. Geneva, 2008.
} 
and their personnel; enact any legislation necessary to provide effective penal sanctions; to provide reparations for violations of international humanitarian law and human rights law caused by the wrongful conduct of the personnel of PMSCs when such conduct is attributable to the State.

The Montreux Document, in accordance with customary international law, addresses the issue of attribution of unlawful conduct of PMSCs to the Contracting State. Thus, the sending State is internationally responsible for such conduct in cases where PMSCs:

- incorporated by the State into their regular armed forces in accordance with its domestic legislation; (subpara. "a" para. 7, section "A", part I);

- members of organized armed forces, groups or units under a command responsible to the State; (subpara. "b" para. 7, section "A", part I);

- empowered to exercise elements of governmental authority if they are acting in that capacity (subpara. "c" para. 7, section "A", part I);

- are in fact acting on the instructions of the State or under its direction or control (subpara. "d" para. 7, section "A", part I).

The rights and obligations of PMSCs and their employees are listed in a separate section. The status of each employee is determined on a case by case basis, taking into account the functions entrusted to him.

The Montreux Document does not provide a list of services that PMSC personnel are entitled to carry out in situations of armed conflict. This approach is predicated on States determining whether to include PMSCs in the armed forces or regulate their activities otherwise. Given the divergent positions and contradictory State practice, the list of military/ security services was left open during the drafting of the Montreux Document. The preface merely provides examples of the services that companies could provide to States. As such, The Montreux Document does not explicitly prohibit the direct participation of PMSC personnel in hostilities.

Unlike the Montreux Document, the International Code of Conduct only recognizes security services, which it construes as "guarding and protection of persons and objects, such as convoys, facilities, designated sites, property or other places (whether armed or unarmed)". ${ }^{25}$ The International Code does not prohibit PMSCs employees from enforcing preventive measures such as detention, transporting de- tainees, and interrogating suspected criminals. The International Code does not contain provisions on the status of staff under international humanitarian law, nor does it take into account the specific environment in which PMSCs operate - the existence of armed conflict.

An important aspect is the award of compensation to victims of the activities of PMSCs. However, neither the Montreux Document nor the International Code contains specific provisions to that effect, leaving it to companies themselves to investigate violations of citizens' rights and to award compensation. The issue of compensation for victims of PMSCs is acute and is further compromised by deferring this to a self-regulatory mechanism. Deficiencies in the Montreux Document and the International Code also include gaps in the regulation of the collection and exchange of evidence in criminal and civil cases between States, extradition, and lack of enforcement and accountability mechanisms [Cockayne 2014: 735-769].

Despite significant shortfalls, State practice indicates that States apply the Montreux Document and the International Code to work with PMSCs. The United States Government strongly encourages companies to apply for membership in the International Code Association as evidence of integrity and quality of service delivery.

\section{Conclusions}

Various UN experts have studied the activities of PMSCs for over 30 years. This led to an intermediate outcome, the drafting of an international convention, which was never adopted by the UN Member States.

1. Negotiations to develop and adopt an international treaty regulating the activities of PMSCs have been suspended. The UN Intergovernmental Working Group is once again studying the possibility of elaborating an international legal regulation without predetermining the nature of the outcome document.

2. Delegations have put forward three different positions on possible legal frameworks:

- The Montreux Document on Pertinent International Legal Obligations and Good Practices for States Related to Operations of Private Military and Security Companies During Armed Conflict, 2008, and the International Code of Private Security Service Providers, 2010;

\footnotetext{
25 The International Code of Conduct for Private Security Service Providers. URL: https://icoca.ch/sites/all/themes/icoca/assets/icoc_russian3.pdf (accessed: 09.09.2020).
} 
- Adoption of an international treaty is not yet required; State practice should first be studied and set out as guidelines;

- An international treaty on the subject is needed. National legislation is fragmented, PMSC personnel violate human rights and, with few exceptions, are legally responsible.

3. The employees of PMSCs do not fall under the definition of a "mercenary" in the sense of Art. 47 Additional Protocol I to the Geneva Conventions of 1949, International Convention of 1989.

4. The status of PMSC personnel under international humanitarian law is determined on a caseby-case basis. If members of PMSCs are incorporated into the State's armed forces, or if they meet the criteria laid down in Article 1 of the 1907 Convention, they may be considered combatants and are entitled to prisoner of war status. In all other cases, PMSC personnel are civilians, which means that they cannot directly participate in hostilities. It is possible to consider them as sui generis participants of armed conflict.

5. Member States did not adopt the draft convention proposed by the experts of the UN Working Group in 2010 because it was silent on crucial

\section{References}

1. Bakker C., Sossai M. Multilevel Regulation of Military and Security Contractors: The Interplay between International, European and Domestic Norms. London: Bloomsbury Publishing. 2012.664 p.

2. Bures O., Carrapiço H. Private security beyond private military and security companies: exploring diversity within private-public collaborations and its consequences for security governance. - Crime Law and Social Change. No. 67(3). 2017. P. 229-243.

3. Cockayne J. Private military and security companies. The Oxford Handbook of International Law in Armed Conflict (Ed. by Claphm A., Gaeta P.) Oxford: Oxford University Press. 2014. 1008 p.

4. Crawford E., Pert A. International Humanitarian Law. Cambridge: Cambridge University Press. 2015. 301 p.

5. Daza F. Delimitation and Presence of PMSCs: Impact on Human Rights. - Public International Law and Human Rights Violations by Private Military and Security Companies (Ed. by Torroja H.) Cham: Springer International Publishing AG. 2017. 158 p.

6. De Nevers R. Private military and security companies. Do the Geneva Conventions Matter? (Ed. by Evangelista M., Tannenwald N.) Oxford University Press. 2017. P. 281302.

7. Gasser M., Malzacher M. Beyond Banning Mercenaries: The Use of Private Military and Security Companies Under IHL. - International Humanitarian Law and Non-State Actors: Debates, Law and Practice (Ed. by Heffes E. et al.) The Hague: Asser Press. 2020. 158 p.

8. Gómez del Prado J.L. The Ineffectiveness of the Current matters, such as the legitimacy of the participation of PMSC personnel in armed conflicts and other governmental functions, the status of PMSC personnel under international humanitarian law, issues of international legal responsibility. In addition, there were differences in the use of such fundamental terms as "inherently governmental functions," "military services", etc.

6. The examination of the Montreux Document revealed that the first part did not contain any innovations, but that the provisions set out were derived mainly from existing sources of international law. The Montreux Document refers to the Articles on Responsibility of States for Internationally Wrongful Acts. The second part of the Montreux Document refers to the national law of States. Additionally, the Montreux Document is non-binding and does not establish a supervision mechanism, one of its significant shortfalls.

7. Given the scale of the numerous human rights violations committed by PMSC personnel, the abuses committed by the companies themselves against workers sent into zones of armed conflict without appropriate legal safeguards, an international treaty on the subject is necessary.

Definition of a "Mercenary" in International Humanitarian and Criminal Law. - Public International Law and Human Rights Violations by Private Military and Security Companies (Ed. by Torroja H.) Cham: Springer International Publishing AG. 2017. 158 p.

9. Kotlyarov I.I. Mezhdunarodno-pravovoe regulirovanie vooruzhennykh konfliktov: osnovnye teoreticheskie problemy i praktika : monografiya. [International Legal Regulation of Armed Conflicts: Main Issues of Theory and Practice: Monograph]. M.: YUrlitinform Publ. 2013. 502 p. (in Russ.)

10. Lehnardt C. Private military contractors. - The Practice of Shared Responsibility in International Law (Ed. by Nollkaemper A., Plakokefalos I.)Cambridge University Press. 2017. P. 761-780.

11. Manoilo A.V., Zaytsev A.Ya. Mezhdunarodno-Pravovoi Status Chastnykh Voennykh Kompanii [International Legal Status of Private Military Companies]. - Herald of the Russian Academy of Sciences. Vol. 90. No. 1. 2020. P. 46-54. (in Russ.)

12. Mathieu F., Rearden N. Corporate Mercenaries: The threat of private military and security companies. - Review of African Political Economy. Vol. 34. No. 114. 2007. P. 744-755.

13. Nebolsina M. Private Military and Security Companies. Russia in Global Affairs. No. 17. 2019.P. 76-106.

14. Rusinova V.N. Klassifikatsiya lits $v$ nemezhdunarodnykh vooruzhennykh konfliktakh: $v$ poiskakh sbalansirovannogo podkhoda. - Gosudarstvo i pravo. No. 3. 2012. P. 61-69. (in Russ.)

15. Sassòli M. International Humanitarian Law: Rules, Controversies, and Solutions to Problems Arising in Warfare. 
Cheltenham: Edward Elgar Publishing Limited. 2019. $720 \mathrm{p}$.

16. Seiberth C. Private Military and Security Companies in International Law. Cambridge: Intersetia. 2014. xlvi + $296 \mathrm{p}$.

17. Skuratova A.Yu., Korol'kova E.E. Smertonosnye av- tonomnye sistemy vooruzhenii: problemy mezhdunarodno-pravovogo regulirovaniya [Lethal Autonomous Weapons Systems: Problems of International Legal Regulation]. - Rossijskij yuridicheskij zhurnal. No. 1 (124). 2019. P. 22-30. (in Russ.)

\section{About the Authors}

\section{Alexandra Yu. Skuratova,}

Cand Sci. (Law), Associate Professor at the Department of International Law,

Moscow State Institute of International Relations (MGIMOUniversity) MFA Russia

76, Prospect Vernadskogo, Moscow, Russian Federation, 119454

interlawmgimo@bk.ru

ORCID: 0000-0001-8513-8719

\section{Elena E. Korolkova,}

Assistance to the Public Prosecutor, Cand Sci. (Law)

Prosecutor's office of the Orenburg region

51, Ul. Kobozeva, Orenburg, Russian Federation,460000

korolkovaintlaw@gmail.com

ORCID: 0000-0001-8932-5044

\section{Информация об авторах}

\section{Александра Юрьевна Скуратова,}

к.ю.н., доцент кафедры международного права

Московский государственный институт международных отношений (Университет) МИД России

119454, Российская Федерация, Москва, проспект Вернадского, д.76

interlawmgimo@bk.ru

ORCID: 0000-0001-8513-8719

\section{Елена Евгеньевна Королькова,}

к.ю.н., помощник прокурора района

Прокуратура Оренбургской области

460000, Российская Федерация, Оренбург, ул. Кобозева, д.51

korolkovaintlaw@gmail.com

ORCID: 0000-0001-8932-5044 